\title{
НОВІ НАПРЯМИ БІОМЕДИЧНОЇ ІНФОРМАТИКИ В СТРАТЕГІЇ ЗМІНЕННЯ ПРАКТИЧНОЇ МЕДИЦИНИ ТА БІОМЕДИЧНОЇ ОСВІТИ. ПРЕЦИЗІЙНА МЕДИЦИНА ТА БІОІНФОРМАТИКА ЗБУДНИКА ЗАПАЛЕННЯ
}

\author{
Л. Ю. Бабінцева, В. В. Краснов \\ Національний університет охорони здоров'я України імені П. Л. Шупика
}

В роботі проаналізовано нові напрями медичної та біологічної інформатики з точки зору засвоєння їх матеріалів і технології транссреру знань. Глобальне призначення цих напрямів полягає в забезпеченні зв'язку між основними концептуальними підходами та конструктами системної медицини та системної біології. Розглянуто два сучасні напрями розвитку системної біомедицини: «прецизійна медицина» (як чисто медичний тренд) та біоінформатика збудника запалення (як чисто біологічний тренд). Запропоновано для трансферу знань активно застосовувати спеціалізовані бази знань, що також являються важливим інструментом біоінорорматики для перевірки патогенності збудника. Представлено методичні прийоми висвітлення досягнень системної біомедицини.

Ключові слова: прецизійна медицина, біоінформатика збудника, системна біомедицина, трансдисциплінарність, інтероперабельність баз знань, фрармакогеноміка.

\section{NEW DIRECTIONS OF BIOMEDICAL INFORMATICS IN THE STRATEGY OF CHANGE OF PRACTICAL MEDICINE AND BIOMEDICAL EDUCATION. PRECISION MEDICINE AND BIOINFORMATICS OF THE INFLAMMATOR}

\author{
L. Yu. Babintseva, V. V. Krasnov \\ Shupyk National Healthcare University of Ukraine
}

Background. The paper analyzes new areas of medical and biological informatics in terms of learning their materials and technology of knowledge transfer. The global purpose of these areas is to provide a link between the basic conceptual approaches and constructs of systems medicine and systems biology. The goal of the work is to present methods of highlighting the achievements of systemic biomedicine.

Materials and methods. Results. Two modern directions of development of systemic biomedicine are considered: "precision medicine" (as a purely medical trend) and bioinformatics of the inflammatory agent (as a purely biological trend). In precision medicine, the main focus is on determining which approaches will be effective for certain patients based on genetic, environmental and life factors. It is proposed to actively use specialized knowledge bases for knowledge transfer, which are also an important tool of bioinformatics to check the pathogenicity of the pathogen.

Conclusions. Researchers can use open data to study a wide range of diseases to better predict the risk of disease, understand its possible course, and find improved strategies for diagnosis and treatment. We regard precision medicine as a fundamentally new direction that enhances the effectiveness of practical medicine. The emergence of systemic biomedicine forces to radically change not only the methods of teaching material, assessing the assimilation of educational content, but also to pay much more attention to the standards of medical care.

Key words: precision medicine, bioinformatics of the pathogen, systemic biomedicine, transdisciplinarity, interoperability of knowledge bases, pharmacogenomics.

\section{НОВЫЕ НАПРАВЛЕНИЯ БИОМЕДИЦИНСКОЙ ИНФОРМАТИКИ В СТРАТЕГИИ ИЗМЕНЕНИЯ ПРАКТИЧЕСКОЙ МЕДИЦИНЫ И БИОМЕДИЦИНСКОГО ОБРАЗОВАНИЯ. ПРЕЦИЗИОННАЯ МЕДИЦИНА И БИОИНФОРМАТИКА ВОЗБУДИТЕЛЕЙ ВОСПАЛЕНИЯ}

\author{
Л. Ю. Бабинцева, В. В. Краснов
}

Национальный университет здравоохранения Украины имени П. Л. Шупика

\begin{abstract}
В работе проанализированы новые направления медицинской и биологической инсорматики с точки зрения технологии транссера знаний. Глобальное назначение этих направлений состоит в обеспечении связи между основными концептуальными подходами и конструктами системной медицины и системной биологии. Рассмотрены два современных направления развития системной биомедицины: «прецизионная медицина» (как чисто медицинский тренд) и биоинформатика возбудителя воспаления (как чисто биологический тренд). Предложено для транссера знаний активно применять специализированные базы знаний, являющиеся также важным инструментом биоинформатики для проверки патогенности возбудителя. Представлены методические приемы освещения достижений системной биомедицины.
\end{abstract}

Ключевые слова: прецизионная медицина, биоинформатика возбудителя, системная биомедицина, трансдисциплинарность, интероперабельность баз знаний, фрармакогеномика.

(с) Л. Ю. Бабінцева, В. В. Краснов 
Вступ. Медична та біологічна інформатика швидко розвиваються. Їхній вплив уже сьогодні досить значний — від зміни характеристик вирішення проблем і міркувань клініциста, до опису координаційних і комунікаційних моделей розподілених клінічних команд, розроблення стійких і когнітивно правдоподібних утручань для підтримки діяльності лікаря. Певна частина досліджень у напряму медичної та біологічної інформатики відноситься до тем прийняття рішень, зручності використання та розподіленої командної діяльності при взаємодії з інформаційними системами. Головним фактором змінення в сучасних біомедичних уявленнях є розвиток системної біомедицини - найважливішого напряму міждисциплінарних і трансдисциплінарних знань. Системна біомедицина як напрям узагальнює багато рівнів абстракції — від математичних (статистика, теорія графів тощо) до додатків до інших великих систем - системної біоінженерії, системної біоінформатики тощо. Глобальне призначення цього напряму полягає в забезпеченні зв'язку між основними концептуальними підходами та конструктами системної біології та системної медицини. В зрозумілому значенні неочевидними стають питання створення відповідної мотивації засвоєння матеріалів нових напрямів і технології трансферу знань. Поява системної біомедицини примушує кардинально змінити не тільки методики викладання матеріалу, оцінювання засвоєння навчального контенту, але й приділити значно більше уваги стандартам надання медичної допомоги.

Мета роботи: представити методичні прийоми висвітлення досягнень системної біомедицини.

Результати та їх обговорення. Системна біомедицина розвивається в низці напрямів. Розглянемо два 3 них - «Прецизійна медицина» (як чисто медичний тренд) та біоінформатика збудника запалення (як чисто біологічний тренд).

Прецизійна медицина та персоналізована медицина мають багато спільного. Більш того, за даними Національної дослідницької ради, «персоналізована медицина» — це більш старий термін із значенням, подібним до терміну «точна медицина» [1]. Хоча деякі дослідники використовують ці два терміни як взаємозамінні чи, навпаки як абсолютно різні.
Термінологічній плутанині сприяє подвійний сенс персоналізованої медицини, що допускає тлумачення напряму як методів лікування та профілактики, які розробляються індивідуально для кожної людини, так й інтегральної тактики забезпечення якісної медичної допомоги з урахуванням факторів ризику, моніторингу станів і прогнозних характеристик. У прецизійній медицині основна увага приділяється визначенню того, які підходи будуть ефективні для тих або інших пацієнтів на основі генетичних, екологічних і життєвих факторів. Нами прецизійна медицина розглядається як принципово новий напрям, що забезпечує підвищення ефективності практичної медицини.

Прийнято, що фармакогеноміка (відносно нова галузь, яка об'єднує фармакологію та геноміку для розроблення ефективних, безпечних лікарських засобів) $є$ частиною прецизійної медицини. Саме фармакогеноміка сприяла виникненню так званої «Ініціативи прецизійної медицини» довгострокової дослідницької роботи за участю Національних інститутів охорони здоров'я (NIH) і багатьох інших дослідницьких центрів із метою зрозуміти, як генетика людини, навколишнє середовище та спосіб життя можуть допомогти визначити найкращий підхід до профілактики або лікування захворювань [2].

Короткостроковою метою «Ініціативи прецизійної медицини» було розширення геноміки раку для розроблення кращих методів профілактики та лікування. У довгостроковій перспективі Ініціатива 3 прецизійної медицини поставила за мету розробити всебічну наукову базу знань, створивши національну мережу вчених і взявши участь у національному когортному дослідженні одного мільйона американців, щоб розширити наше розуміння здоров’я та хвороб [3]. Отже, Ініціатива прецизійної медицини переслідує як короткострокові, так і довгострокові цілі. Узагальнюючи зазначене, можемо сказати, що короткострокові цілі включають, перш за все, розширення прецизійної медицини в області досліджень онкологічних захворювань. Довгострокові цілі зосереджені на тому, щоб привести прецизійну медицину в усі області охорони здоров'я. Для реалізації довгострокових цілей NIH запустила дослідження, відоме як All of Us Research Program, на всій території США. Учасники надають генетичні дані, біологічні 
зразки та іншу інформацію про своє здоров’я. Щоб стимулювати відкритий обмін даними, учасники можуть отримати доступ до своєї медичної інформації, а також до досліджень, що використовують їхні дані. Дослідники, в свою чергу, можуть використовувати ці дані для вивчення широкого спектру захворювань для кращого прогнозування ризику виникнення захворювання, розуміння його можливого перебігу, а також пошуку поліпшених стратегій діагностики та лікування [4].

Другим напрямом системної біомедицини, що пропонується для розгляду з точки зору нової парадигми трансферу знань і важливим інструментом біоінформатики являється можливість перевірки патогенності щойно відкритого бактеріального збудника за допомогою спеціальних баз знань. В якості прикладу звернемо увагу на Pathogen Finder 1.1 (https://cge.cbs.dtu.dk/services/ PathogenFinder/). PathogenFinder - це веб-сервер, що використовується для прогнозування бактеріальної патогенності з використанням протеомних, геномних або необроблених даних. Цей веб-сервер може передбачити патогенність для всіх таксономічних груп бактерій із точністю 88,6 \%. Підхід програми не упереджений із відомою патогенністю. Тому програма може бути використана для виявлення нових факторів патогенності.

Останнім відомим методом прогнозування патогенності є PaPrBaG (передбачення патогенності для геномів бактерій) (https:/github.com/crarlus/ paprbag), заснований на машинному навчанні та представлений у вигляді пакету R [5]. PaPrBaG прогнозує патогенність шляхом тренувань на великій кількості встановлених патогенних видів у порівнянні з непатогенними бактеріями. Підходить для даних NGS (секвенування нового покоління) з дуже низьким геномним покриттям. PaPrBaG - метод на основі випадкових дерев прийняття рішень для оцінювання патогенного потенціалу набору зчитувань, що належать до одного геному. Це допомагає у прогнозуванні нових, невідомих бактеріальних збудників. PaPrBaG забезпечує прогнозування на відміну від інших підходів, що відкидають багато зчитувань послідовності на основі низької схожості з відомими контрольними геномами.

Важливим фактором впливу на прийняття рішень $\epsilon$ можливість забезпечення інтероперабельності різних баз знань. Так, послідовність і функції генів вірулентності, що відповідають різним основним факторам бактеріальної вірулентності конкретного патогену, можуть бути зібрані з GenBank i перевірені за допомогою факторів вірулентності бази даних патогенних бактерій (http://www.mgc.ac.cn/ VFs/), програми пошуку факторів вірулентності (http://www.phidias.us/victors/) — Victors (англ. Virulence factors), що включає на сьогоднішній день 5304 вірулентних фактори та інструменти ресурсного центру бактеріальної біоінформатики - PATRIC (англ. — the Pathosystems Resource Integration Center) - Центр інтеграції ресурсів систем патології, що надає інтегровані дані та інструменти аналізу для підтримки біомедичних досліджень при бактеріальних інфекційних захворюваннях (https://www.patricbrc.org/). Зрозуміло, що гарантується професіональна орієнтація при використанні баз знань: для того, щоб використовувати всі інструменти та посилання, надані PATRIC, користувачеві слід зареєструватися на головному порталі веб-сайту. Навіть при накопиченому на цей час досвіді застосування баз знань, можна лише дивуватися швидкості розробок у напряму використання інформаційних технологій. Проте основним питанням залишаються застосовувані методи інформаційної педагогіки для навчання лікарів сучасним можливостям прецизійної медицини та біоінформатики.

Засоби біоінформатики для виявлення та боротьби 3 антимікробною стійкістю. Потреба у швидкому, точному виявленні та розумінні факторів резистентності та їхніх механізмів вельми актуальна в дослідженні антимікробної стійкості. Контиги геному можуть бути, в першу чергу, досліджені на наявність локусів стійкості до антибіотиків за допомогою служб анотації генів як PGAAP, так і PATRIC. Крім того, наявність локусів стійкості до антибіотиків для нещодавно виділених бактеріальних патогенів можна потім дослідити за допомогою спеціалізованих інструментів і служб пошуку, а саме пошуку генів антибіотичної стійкості (https://www.patricbrc.org/), Finder Feature Finder (стійкість до антибіотиків), ARDB (База даних генів антибіотикорезистентності) (https://ardb.cbcb. umd.edu/), CARD (Комплексна база даних резистентності до антибіотиків) (https://card.mcmaster. ca/). Спеціальний пошук генів і ResFinder 2.1 ідентифікують набуті гени антимікробної стійкості 
та/або виявляють хромосомні мутації у загальних або частково секвенованих ізолятах бактерій [6]. ResFinder - веб-сервер, що забезпечує відповідний спосіб ідентифікації набутих генів антимікробної стійкості у повністю секвенованих ізолятах. Доступ до нього можна отримати за адресою: www.genomicepidemiology.org. ResFinder регулярно оновлюється стосовно стійкості нових генів. Подібним чином, антибактеріальні гени біоциду та стійкості до металів також можна дослідити за допомогою PGAAP, служб анотації генів PATRIC, інструменту пошуку PATRIC Feature Finder та BacMet (база даних антибактеріальних біоцидів і стійкості до металів) (http://bacmet.biomedicine. gu.se/). P.mirabilis SCDR1, перший наносрібно стійкий ізолят, містить фактори патогенності та вірулентності для встановлення успішної інфекції. P.mirabilis SCDR1 містить декілька механізмів стійкості до антибіотиків і металів, включаючи формування біоплівки, ройову рухливість, системи відтоку та ферментативну детоксикацію. P.mirabilis SCDR1 має кілька механізмів, що можуть призвести до спостережуваної стійкості до наносрібла [7].

\section{Література.}

1. Медицинские информационные системы. Перспективы развития / Зубов Е. В., Гатаутдинова Г. Ф., Гуляева О. В. // Актуальные вопросы педиатрии : матер. межрег. науч.-практ. конф. с междун. уч. - 08 апреля 2017, г. Пермь. - С. 79-83.

2. Developing genomic knowledge bases and databases to support clinical management: current perspectives / Huser V., Sincan M., Cimino J. J. // Pharmgenomics Pers Med. - 2014. - № 7. - P. 275-283.

3. Precision Medicine Initiative: Data Security Policy Principles and Framework. - The white house. May 25, 2016.

4. Ashley E. Towards precision medicine / Ashley E. // Nat Rev Genet. - 2016. - № 17. - P. 507-522.

5. PaPrBaG: A machine learning approach for the detection of novel pathogens from NGS data: Sci Rep / Deneke C., Rentzsch R., Renard B. // Nature. - 2017. № 7. - P. 39194.

6. Identification of acquired antimicrobial resistance genes / Zankari E. et al. // J. Antimicrob. Chemother. 2012. - № 67. - P. 2640-2644.
Висновки. 1. Нові напрями медичної та біологічної інформатики потребують вивчення технологій передавання знань. Їх глобальна мета полягає у забезпеченні зв'язку між системною медициною та системною біологією.

2. Дослідники можуть використовувати відкриті дані для вивчення широкого кола захворювань, щоб краще передбачити ризик захворювання, зрозуміти його можливий перебіг та знайти вдосконалені стратегії діагностики та лікування.

3. Для передавання знань запропоновано активно використовувати спеціалізовані бази знань, що також є важливим інструментом біоінформатики для перевірки патогенності збудника.

4. Точна медицина нами розглядається як принципово новий напрям, що підвищує ефективність практичної медицини.

5. Поява системної біомедицини змушує кардинально змінювати не тільки методи викладання матеріалу, оцінюючи засвоєння освітнього змісту, а й приділяти набагато більше уваги стандартам медичної допомоги.

7. Genome sequencing and analysis of the first spontaneous Nanosilver resistant bacterium Proteus mirabilis strain SCDR1 / Saeb A. T. M., Khalid A. AlR., Abouelhoda M. et al. // Antimicrobial Resistance \& Infection Control. - 2017. - № 6.

8. Saeb A. T. M. Current Bioinformatics resources in combating infectious diseases / Saeb A. T. M. // Bioinformation. - 2018. - № 14 (1). - P. 031-035.

9. PathogenFinder - Distinguishing Friend from Foe Using Bacterial Whole Genome Sequence Data / Cosentino S., Voldby L. M., Møller A. F., Lund O. // PLoS ONE. - 2013. - № 8 (10). - P. e77302.

10. Culture andbehaviour in theEnglishNational Health Service: overview of lessons from a large multimethod study / Dixon-Woods R. B., Charles K., Dawson J. et al. // BMJ Qual. Saf. - 2014. - № 23 (2). - P. 106-115. 


\section{References.}

1. Zubov, E.V., Gatautdinova, G.F., Gulyaeva, O.V. (2017). Medical information systems. Prospects for development. Actual problems of pediatrics: mater. mezhreg. scientific-practical conf. from intern. uch. 08 April 2017, Perm, 79-83.

2. Huser, V., Sincan, M., Cimino, J. J. (2014). Developing genomic knowledge bases and databases to support clinical management: current perspectives. Pharmgenomics Pers Med, 7, 275-283.

3. Precision Medicine Initiative: Data Security Policy Principles and Framework. - The white house. May 25, 2016.

4. Ashley, E. (2016). Towards precision medicine. Nat Rev Genet, 17, 507-522.

5. Deneke, C., Rentzsch, R., Renard, B. (2017). PaPrBaG: A machine learning approach for the detection of novel pathogens from NGS data: Sci Rep. Nature, 7, 39194.
6. Zankari, E. et al. (2012). Identification of acquired antimicrobial resistance genes. J. Antimicrob. Chemother, 67, 2640-2644.

7. Saeb, A. T. M., Khalid, A. Al-R., Abouelhoda, M. et al. (2017). Genome sequencing and analysis of the first spontaneous Nanosilver resistant bacterium Proteus mirabilis strain SCDR1. Antimicrobial Resistance \& Infection Control, 6.

8. Saeb, A. T. M. (2018). Current Bioinformatics resources in combating infectious diseases. Bioinformation, 14 (1), 031-035.

9. Cosentino, S., Voldby, L. M., Møller, A. F., Lund, O. (2013). PathogenFinder - Distinguishing Friend from Foe Using Bacterial Whole Genome Sequence Data. PLoS ONE, 8 (10), e77302.

10. Dixon-Woods, R. B., Charles, K., Dawson, J. et al. (2014). Culture and behaviour in the English National Health Service: overview of lessons from a large multimethod study. BMJ Qual. Saf., 23 (2), 106-115. 